\title{
Expression of mRNA for Interleukin-5 in Mucosal Bronchial Biopsies from Asthma
}

Q. Hamid, May Azzawi, Sun Ying, R. Moqbel, A. J. Wardlaw, C. J. Corrigan, B. Bradley,

S. R. Durham, J. V. Collins, ${ }^{*}$ P. K. Jeffery," Diana J. Quint," and A. B. Kay

Departments of Allergy and Clinical Immunology, and ${ }^{*}$ Lung Pathology, National Heart and Lung Institute, and ${ }^{\ddagger}$ Royal Brompton

Hospital, London, and Biochemistry Department, Glaxo Research Ltd., Greenford, Middlesex, United Kingdom

\begin{abstract}
We have attempted to identify mRNA for IL-5 in endobronchial mucosal biopsies from asthmatics and controls, using the technique of in situ hybridization. Bronchial biopsies were obtained from 10 asthmatics and 9 nonatopic normal controls. $A$ radio-labeled cRNA probe was prepared from an IL-5 cDNA and hybridized to permeabilized sections. These were washed extensively before processing for autoradiography. An IL-5producing $T$ cell clone derived from a patient with the hyperIgE syndrome was used as a positive control. As a negative control, sections were also treated with a "sense" IL-5 probe. Specific hybridization signals for IL-5 mRNA were demonstrated within the bronchial mucosa in 6 out of the 10 asthmatic subjects. Cells exhibiting hybridization signals were located beneath the epithelial basement membrane. In contrast, there was no hybridization in the control group. No hybridization was observed with the sense probe.

The six IL-5 mRNA-positive asthmatics tended to have more severe disease than the negative asthmatics, as assessed by symptoms and lung function, and showed a significant increase in the degree of infiltration of the bronchial mucosa by secreting (EG2 +) eosinophils and activated (CD25+) T lymphocytes. Within the subjects who showed positive IL-5 mRNA, there was a correlation between IL-5 mRNA expression and the number of CD25+ and EG2 + cells and total eosinophil count.

This study provides evidence for the cellular localization of IL-5 mRNA in the bronchial mucosa of asthmatics and supports the concept that this cytokine regulates eosinophil function in bronchial asthma. (J. Clin. Invest. 1991. 87:15411546.) Key words: interleukin-5 • asthma • T cells • eosinophils • hybridization
\end{abstract}

\section{Introduction}

Asthma is characterized by infiltration of the bronchial mucosa with large numbers of activated eosinophils and the presence of elevated concentrations of eosinophil-derived proteins such as major basic protein (MBP) 1 (1) and the eosinophil cationic

Address correspondence to A. B. Kay, Professor and Director, Dept. of Allergy and Clinical Immunology, National Heart and Lung Institute, Dovehouse Street, London, SW3 6LY, UK.

Received for publication 11 July 1990 and in revised form 27 December 1990.

1. Abbreviations used in this paper: con A, concanavalin A; ECP, eosinophil cationic protein; MBP, major basic protein; PAF, platelet activating factor.

J. Clin. Invest.

(c) The American Society for Clinical Investigation, Inc.

0021-9738/91/05/1541/06 \$2.00

Volume 87, May 1991, 1541-1546 protein (ECP) (2). The degree of the eosinophilia has been shown to correlate with the severity of airways hyperresponsiveness (3). In a primate model of asthma, inhibition of the eosinophilic response to allergen substantially blocked the development of airways hyperresponsiveness (4). Eosinophil-derived mediators have potential for producing many of the pathological features of asthma. For example, epithelial shedding is believed to occur through the cytotoxic effects of secreted eosinophil granule proteins (5) and mucus hypersecretion and bronchoconstriction through the release of platelet activating factor (PAF) and leukotriene $\mathrm{C}_{4}(6)$. Recent studies have also suggested a role for $\mathrm{T}$ lymphocytes in asthma. $\mathrm{T}$ lymphocyte infiltration is a feature of the late-phase response to allergen in atopic individuals in both the skin (7) and lung (8). Increased numbers of activated $T$ cells and concentration of their products have been observed in the peripheral blood of acute severe asthmatics (9). More recently, by specific immunostaining of bronchial mucosal biopsies obtained via the fiberoptic bronchoscope, we have demonstrated a significant increase in numbers of positive IL-2 receptor bearing cells in the airways of mild, steady-state asthmatics (10). This was associated with an elevation in the numbers of EG2+ (EG2 is a monoclonal antibody which recognizes the secreted, cleaved form of the eosinophilic cationic protein) (11).

It has been known for several years that $T$ lymphocytes play a central role in eosinophil production and function through the release of soluble mediators. A number of cytokines with selective actions on eosinophils have now been sequenced and cloned. One of the most important is IL-5 which promotes terminal differentiation of the committed eosinophil precursor (12) as well as enhancing the effector capacity of mature eosinophils (13). IL-5 also prolongs the survival of eosinophils in vitro (14). For example, antibodies against IL-5 ablate the eosinophilic response to parasitic infection in mouse (15) and an IL-5-like substance has been found in the serum of patients with hypereosinophilia (16). Of particular interest is the observation that IL-5 increases eosinophil, but not neutrophil, adhesion to vascular endothelium (17). Release of IL-5 at the site of allergic inflammation could explain, in part, the specific eosinophil accumulation seen in these conditions. Similarly release of IL-5, in and around the bronchial mucosa, by activated T lymphocytes could lead to the specific recruitment of eosinophils, enhanced eosinophil cytotoxicity and prolonged eosinophil survival. Identification of mRNA for IL-5 in the bronchi of asthmatics might provide important evidence of IL-5 generation as well as emphasizing the possible link between eosinophils and $\mathrm{T}$ lymphocytes in this disease. We have therefore used the technique of in situ hybridization using an IL-5 cRNA probe to investigate the expression of IL-5 mRNA and the pattern of distribution of IL-5-producing cells in bronchial tissue obtained from biopsies of asthmatics and normal individuals. We have also attempted to relate the expression of IL-5 mRNA 
to the severity of the disease and the degree of infiltration of the airway mucosa with eosinophils and activated $\mathrm{T}$ lymphocytes.

\section{Methods}

Bronchial biopsies. The technique of fiberoptic bronchoscopy with bronchial biopsies in asthmatic volunteers and normal controls has been described in detail elsewhere (10). In the present study, bronchial biopsies from a further 19 subjects were obtained. These included 10 atopic asthmatics (skin test positive to common inhalant aeroallergens) and nine nonatopic normal controls (see Table I for clinical details). The asthmatic subjects were recruited from the Allergy Clinic, Royal Brompton and National Heart Hospital. The diagnosis of asthma was as previously described (1). In brief, all the patients had typical clinical symptoms, documented airways reversibility and increased airway responsiveness (methacholine $\mathrm{PC}_{20}<8 \mathrm{mg} / \mathrm{ml}, \mathrm{PC}_{20}$ being the provocation concentration of inhaled methacholine that caused a $20 \%$ decrease in $\mathrm{FEV}_{1}$ ). Seven asthmatics (termed symptomatic [S]) had frequent symptoms (daily in five of the subjects) which were controlled by the regular usage of inhaled selective $\beta 2$-agonists. The remainder required only occasional $\beta 2$-agonists and had been asymptomatic (A) for at least $1 \mathrm{wk}$ before the fiberoptic bronchoscopy. None of the asthmatics had taken inhaled or oral corticosteroids or other prophylactic treatment in the preceding $3 \mathrm{mo}$. The nonatopic healthy control subjects were recruited from among laboratory staff and students. All subjects (asthmatics and controls) were nonsmokers. The study was performed with informed written consent and with the approval of the Royal Brompton and National Heart Hospital Ethics Committee. For each subject, baseline spirometry $\left(\mathrm{FEV}_{1}\right)$ was recorded and a methacholine inhalation test $\left(\mathrm{PC}_{20}\right)$ was performed. Bronchial biopsies were obtained from the subsegmental airways as described (10). Nebulized salbutamol was given to all subjects (asthmatics and controls) before the bronchoscopy procedure. The biopsies were snap frozen in isopentane cooled in liquid nitrogen and stored in $-70^{\circ} \mathrm{C}$.

In situ hybridization. IL-5 cDNA (a gift from Dr. C. J. Sanderson, National Institute for Medical Research, London) was obtained as pEDF-H2 1 in a pGEM 4 vector and used as a template for synthesizing IL-5 RNA probes (18). In initial experiments, RNA probes generated from IL-5 oligonucleotides according to Tavernier et al. (19) (a gift from E. Kawashima) were used. The probes were well characterized previously $(18,19)$. Both probes gave virtually identical results. IL-5 cDNA was inserted into a pGEM 4 vector and linearized with Xba 1 or Bam $\mathrm{H} 1$ to produce antisense (having a complementary sequence to IL-5 mRNA) or sense (having identical sequence to IL-5 mRNA) probes, respectively. Labeled antisense (cRNA) or sense (mRNA) transcripts of IL-5 cDNA were synthesized in the presence of ATP, GTP, and CTP, $\left(-{ }^{32} \mathrm{P}\right)$ UTP, and SP-6 polymerase or T7 polymerase to generate antisense or sense probe, respectively (20). For in situ hybridization, cryostat sections $(10 \mu \mathrm{m})$ were cut from the biopsies on poly-L-lysine coated slides, allowed to dry for $10 \mathrm{~min}$ and fixed in freshly prepared solution of $4 \%$ paraformaldehyde in $0.1 \mathrm{M} \mathrm{PBS} \mathrm{(pH} \mathrm{7.4)} \mathrm{for} 30 \mathrm{~min}$ at $4^{\circ} \mathrm{C}$. Sections were then washed with PBS containing $15 \%$ sucrose and allowed to dry for $12 \mathrm{~h}$ at $37^{\circ} \mathrm{C}$ before processing. Sections from the biopsies were first permeablized with a $0.3 \%$ solution of Triton X-100 in PBS for $10 \mathrm{~min}$ and then with a proteinase $\mathrm{K}(1 \mu \mathrm{g} / \mathrm{ml})$ in $0.1 \mathrm{M}$ Tris containing $50 \mathrm{mM}$ EDTA for $20-30 \mathrm{~min}$ at $37^{\circ} \mathrm{C}$. The reaction was terminated by immersion of the preparations in $4 \%$ paraformaldehyde for $5 \mathrm{~min}$. The preparations were then treated in $0.25 \%$ acetic anhydride in $0.1 \mathrm{M}$ triethanolamine for $10 \mathrm{~min}$ to reduce nonspecific binding and prehybridized in $50 \%$ formamide and $2 \times$ standard saline citrate (SSC) for $30 \mathrm{~min}$ at $40^{\circ} \mathrm{C}$. For hybridization, $6 \mathrm{ng}$ of radiolabeled antisense or sense probe $\left(=10^{6} \mathrm{cpm} / \mathrm{section}\right)$ diluted in hybridization buffer (21) was used. The preparations were covered with dimethyldichlorosilane-coated coverslips and hybridization was performed in a humid chamber for $16 \mathrm{~h}$ at $40^{\circ} \mathrm{C}$. Posthybridization washing was performed in a decreasing concentration of SSC $(4 \times$ SSC- $0.05 \times$ SSC $)$ at $45^{\circ} \mathrm{C}$. Unhybridized single-stranded RNAs were removed by treating the preparations with a solution containing RNase A $(20 \mu \mathrm{g} / \mathrm{ml}), 0.5 \mathrm{M}$ $\mathrm{NaCl}, 10 \mathrm{mM}$ Tris, and $1 \mathrm{mM}$ EDTA for $30 \mathrm{~min}$ at $42^{\circ} \mathrm{C}$.

After dehydration, the sections were immersed in K-5 emulsion (Ilford, UK), and exposed for $72 \mathrm{~h}$. The autoradiographs were developed in Kodak D-19, fixed with hypam (Ilford) and counterstained with hematoxylin.

As a positive control, a peripheral blood $\mathrm{T}$ lymphocyte clone was obtained from a patient with the hyper-IgE syndrome (22). This clone was shown to express IL-5 mRNA with the PCR technique (data not shown) and was also shown to secrete IL-5 into the culture supernatant after activation with concanavalin A (con A). Cytospins of these cells were prepared before and after stimulation and processed and hybridized as described for the biopsies. For negative controls, a separate set of sections from bronchial biopsies, and IL-5-producing T cell cytospins were hybridized with sense IL-5 probes. A further control involved the treatment of a separate set of preparations with RNase-A solution (20 $\mu \mathrm{g} / \mathrm{ml}$ ) at $37^{\circ} \mathrm{C}$ for $40 \mathrm{~min}$ before the prehybridization step. Hybridization was subsequently performed with labeled IL- 5 CRNA, as described above. No hybridization signals were observed with these procedures, thus confirming the specificity of the results obtained during hybridization with cRNA probes. Because hybridization with ${ }^{32} \mathrm{P}$-labeled probe does not enable distinct grain counting, positive (as opposed to negative) hybridization was determined by the demonstration of clear differences between the density of silver grains on individual cells when hybridized with either antisense or sense probes.

Immunocytochemistry. The APAAP procedure used here has been described in detail elsewhere (7). Cryostat sections $(6 \mu \mathrm{m})$ were cut from the frozen bronchial biopsies. They were air dried for $1 \mathrm{~h}$, fixed in a mixture of equal parts acetone:methanol for $2 \mathrm{~min}$, and stained with monoclonal antibodies anti-CD25 (anti-IL-2 receptor) and EG2 (an antibody directed against the cleaved form of eosinophil cationic protein) as well as anti-CD4, CD3, CD45, and CD8. Sections were also stained with carbol chromotrope 2R for total eosinophil counts. Positively stained or hybridized cells were counted in a $115-\mu \mathrm{m}$ zone along the entire length of epithelial basement membrane. A calibrated and computerized graphics tablet (Apple Ile) was used to determine the length of basement membrane. Cell counts were expressed per unit length $(1,000 \mu \mathrm{m})$ of basement membrane.

Statistics. Comparisons between cell counts and lung function in the IL-5 mRNA-positive asthmatics and IL-5 mRNA-negative asthmatics were performed using the Mann-Whitney test for unpaired samples. Correlation coefficients were obtained by Kendall's rank method with correction for tied values. $P$ values $<0.05$ were considered significant.

\section{Results}

Hybridization between the labeled cRNA probes and mRNA encoding IL-5 mRNA was demonstrated by specific deposits of silver grains in the photographic emulsion overlying the tissue sections or the positive control cytospins (Figs. 1-6). The intensity of the hybridization signal was similar in both bronchial biopsies and the positive control T-cell clone. The two probes employed (cRNA generated from IL-5 cDNA or from an IL-5 oligonucleotide) gave virtually identical results under the same hybridization conditions. The specificity of both the probe and the hybridization was confirmed by $(a)$ the presence of intense labeling of up to $40 \%$ of cells of cytospin preparations of the IL-5-producing $\mathrm{T}$ cell clone after, but not before stimulation with con A (Figs. 1 and 2 ), and (b) the absence of hybridization when all the preparations were treated with a "sense" probe (Fig. 3), or after treatment with RNAase before the application of the labeled IL-5 cRNA (Fig. 4). Furthermore the signal was still clearly detectable under high stringency washing (tempera- 

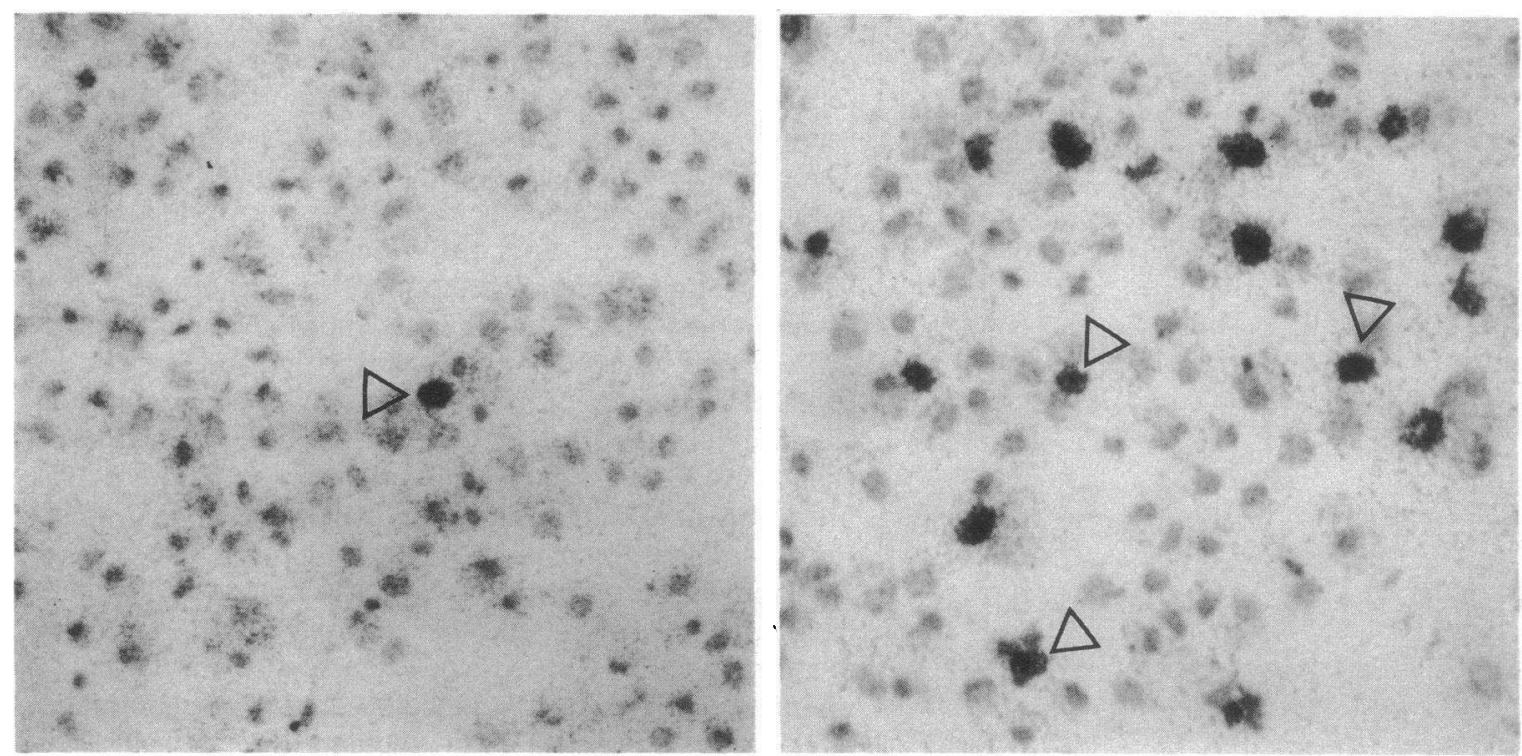

Figures 1 and 2. Autoradiographs of a cytospin preparations prepared from human T cell clone before (left) and after (right) stimulation with con A. In situ hybridization was performed with ${ }^{32} \mathrm{P}$-labeled IL-5 cRNA probe. Arrows indicate the positive IL-5 mRNA signals. Note the difference in the number of IL-5-positive cells. Magnification for Fig. 1 and 2, 400.

ture $45^{\circ} \mathrm{C}$ and $0.05 \times$ SSC) (Fig. 5). There were positive hybridization signals in 6 of the 10 bronchial biopsies obtained from asthmatic subjects (Table I). Cells with a positive hybridization signal were located mainly below the basement membrane extending down to the level of bronchial smooth muscle. They were scattered among inflammatory infiltrates within the bronchial mucosa. The positive cells were rounded and relatively small compatible with the shape and size of lymphocytes. The intensity of hybridization and the number of positive cells varied from 6 to 20 per millimeter length of basement membrane (Table II). There was no hybridization signal on the epithelial

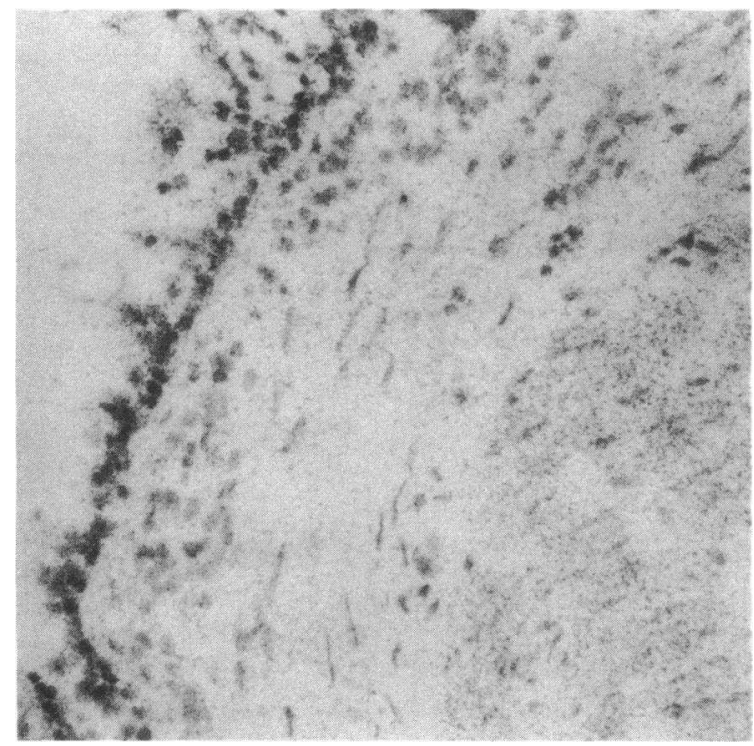

Figure 3. Autoradiograph of bronchial mucosa from a patient with symptomatic asthma. The section was hybridized with a sense (control) probe. Note the absence of any hybridization signal (magnification, 280). or endothelial cells. Biopsies from the normal controls did not show any hybridization signal (Fig. 6).

A positive signal for IL-5 mRNA was observed in six of the seven symptomatic asthmatics and none of the three asymptomatic asthmatics (Table I). There was a trend (nonsignifcant) for the six patients who were IL-5 mRNA-positive to have a lower $\mathrm{FEV}_{1}$ percent predicted (range, 62.4-104) and $\mathrm{PC}_{20}$ methacholine (0.05-3.0) when compared with the four asthmatics who were IL-5 mRNA negative $\left(\mathrm{FEV}_{1}, 91-97\right.$; $\mathrm{PC}_{20}, 2.0-5.5$ ).

Quantification of IL-5 mRNA-positive cells below the base-

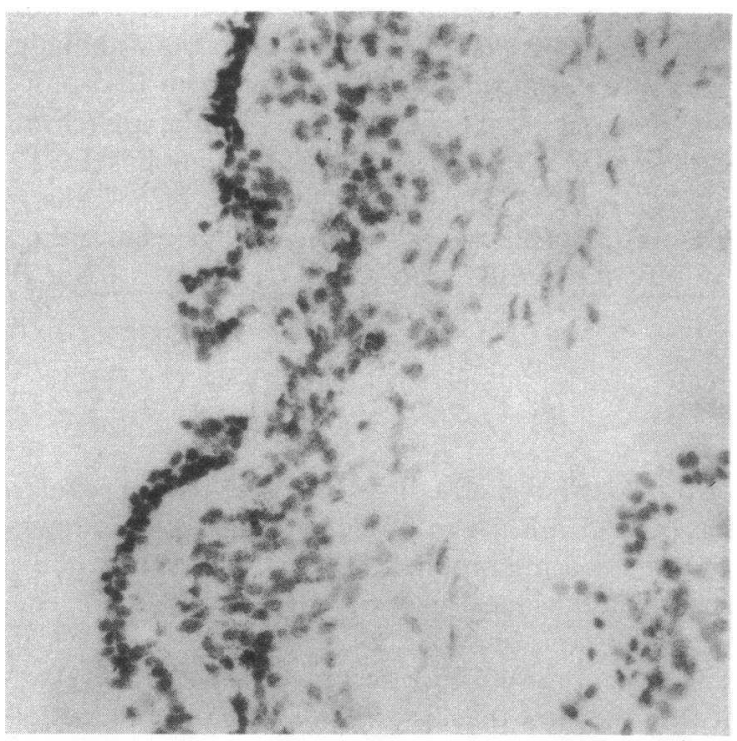

Figure 4. Autoradiograph from bronchial mucosa from patient with asthma. The section was treated with RNase before hybridization with the radiolabeled IL-5 cRNA probe. No hybridization was detected (magnification, 300). 


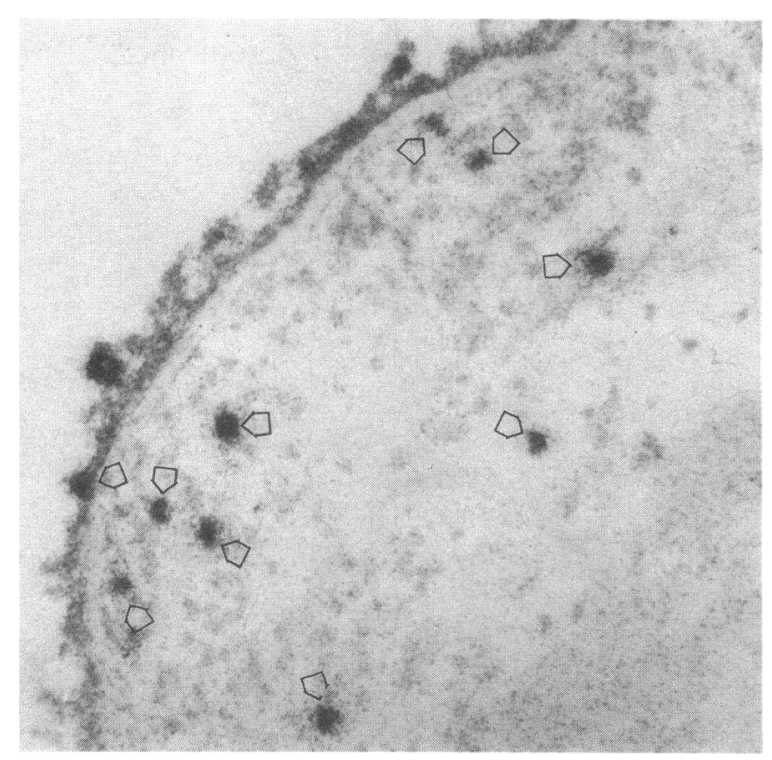

Figure 5. Autoradiograph of bronchial mucosa from a patient with symptomatic asthma. In situ hybridization was performed under high stringency with ${ }^{32} \mathrm{P}$-labeled cRNA probe encoding for IL-5 mRNA. Arrows indicate the positive IL-5 mRNA cells (magnification, 300).

ment membrane is shown in Table II. The numbers were compared to the eosinophil counts (chromotrope 2R) and the number of EG2+ and CD25+ cells. Biopsies from the six asthmatics, showing a positive IL-5 mRNA signal, had significantly greater numbers of eosinophils (chromotrope 2R), EG2+ cells and CD25+ cells compared with the four negative asthmatics (Table III). There was no significant difference in the number of CD45+, CD4+, CD3+, and CD8+ cells between asthma and control. This is in agreement with our previous finding (10). Biopsies from the nine normal healthy controls were negative for IL-5 mRNA, and contained very few eosinophils (chromotrope $2 \mathrm{R}$ ), EG2+ or CD25+ cells. Within the asthmatic group, there were significant correlations between IL-5-positive cells and the total number of infiltrating eosinophils (chromotrope $2 \mathrm{R}+, r=0.52, P<0.05$ ), activated eosinophils (EG2 ${ }^{+}$ cells, $r=0.71, P<0.01)$ and activated T cells (CD25+ cells, $r$ $=0.80, P<0.01)$. There was also a significant relationship between numbers of EG2+ and CD25+ cells $(r=0.55, P$ $<0.05)$.

\section{Discussion}

This study provides novel and direct evidence for the cellular localization of IL-5 mRNA in bronchial mucosa in asthma. Messenger RNA is a midproduct between gene transcription and translation, and its localization provides evidence of gene expression and suggests but does not prove active synthesis of the relevant protein (21). Thus, the results reported here are consistent with the view that IL-5 is an important product of the inflammatory process associated with allergic asthma.

The localization of IL-5 mRNA was demonstrated by the technique of in situ hybridization. We have used radiolabeled RNA probes, already shown to be the most specific and sensitive among other types of probes $(20,23)$. In addition, we un- dertook extensive control procedures to ensure the specificity of the hybridization, including the use of an IL-5-producing T cell clone, sense probes, and RNase pretreatment. The hybridization was carried out also under high-stringency conditions. The presence of strong hybridization in the $\mathrm{T}$ cell clones, the stability of the signal after the high-stringency washing, and the absence of hybridization with either sense probes or after RNase treatment confirmed the specificity of both the probes as well as the signal. Eosinophils are known to bind ${ }^{35} \mathrm{~S}$-labeled RNA probes nonspecifically. However, in the present study ${ }^{32} \mathrm{P}$-labeled probes were employed; these have much lower nonspecific binding properties (24). Moreover, the absence of specific hybridization signal with the sense probe, or after RNase pretreatment excludes the possibility that the signal we observed was nonspecific binding to eosinophils.

Positive IL-5 mRNA cells were distributed among the inflammatory cells within the bronchial mucosa. We were unable to ascertain the precise cell type expressing IL-5 mRNA. IL-5 was first described as a $\mathrm{T}$ lymphocyte-derived mediator; therefore, $\mathrm{T}$ cells are the most likely candidate cell, especially as the positive cells had a consistently lymphocytic morphology and their distribution reflect that of the CD25+ cells. Nevertheless, we cannot rule out the possibility of IL- $5 \mathrm{mRNA}$ expression by alternative cell types, such as the mast cells (25). Whatever the cell type involved we believe that our finding of increased numbers of mRNA-positive cells in asthma as opposed to control is of considerable interest for the reasons stated.

In the present study only 6 out of 10 asthmatics were positive for IL-5 mRNA. The lack of an IL-5 mRNA signal in the

Table I. Expression of mRNA for IL-5 in the Bronchial Mucosa in Asthmatics and Controls in Relation to Asthma Severity, Age, Gender, FEV $V_{1}$ Percent Predicted and Bronchial Hyperresponsiveness ( $\left.P C_{20}\right)$

\begin{tabular}{lrrccc}
\hline $\begin{array}{c}\text { Group } \\
\text { (Asthma severity) }\end{array}$ & Pt. No. & Age/sex & FEV $_{1}$ & PC $_{20}$ & IL-5mRNA \\
\hline & & & \% predicted & $m g / m l$ & \\
Symptomatic & 1 & $23 \mathrm{~F}$ & 75 & 0.3 & + \\
Symptomatic & 2 & $21 \mathrm{~F}$ & 104 & 2.0 & + \\
Symptomatic & 3 & $30 \mathrm{~F}$ & 62.4 & 0.05 & + \\
Symptomatic & 4 & $20 \mathrm{~F}$ & 90 & 2.8 & + \\
Symptomatic & 5 & $21 \mathrm{M}$ & 91 & 3.0 & + \\
Symptomatic & 6 & $20 \mathrm{~F}$ & 79 & 1.2 & + \\
Symptomatic & 7 & $27 \mathrm{M}$ & 90 & 2.4 & - \\
Asymptomatic & 8 & $20 \mathrm{~F}$ & 91 & 2.7 & - \\
Asymptomatic & 9 & $21 \mathrm{M}$ & 97 & 5.5 & - \\
Asymptomatic & 10 & $19 \mathrm{~F}$ & 97 & 2.0 & - \\
& & & & & \\
Normal & 11 & $26 \mathrm{M}$ & 120 & 32 & - \\
Normal & 12 & $25 \mathrm{M}$ & 116 & 32 & - \\
Normal & 13 & $30 \mathrm{M}$ & 94 & 32 & - \\
Normal & 14 & $22 \mathrm{~F}$ & 112 & $>32$ & - \\
Normal & 15 & $29 \mathrm{M}$ & 107 & $>32$ & - \\
Normal & 16 & $25 \mathrm{~F}$ & 116 & $>32$ & - \\
Normal & 17 & $30 \mathrm{M}$ & 100 & $>32$ & - \\
Normal & 18 & $22 \mathrm{~F}$ & 118 & $>32$ & - \\
Normal & 19 & $24 \mathrm{~F}$ & 120 & $>32$ & - \\
& & & & & \\
\hline
\end{tabular}

Symptomatic subjects were those who had symptoms in the week before biospy. 
Table II. Numbers of IL-5 mRNA-positive Cells in Relation to Eosinophil Counts and Numbers of $\mathrm{EG2}^{+}$and $\mathrm{CD}_{25} 5^{+}$Cells in the Bronchial Mucosa

\begin{tabular}{lrrrrr}
\hline $\begin{array}{c}\text { Group } \\
\text { (asthma severity) }\end{array}$ & $\begin{array}{c}\text { Subject } \\
\text { No. }\end{array}$ & $\begin{array}{c}\text { IL-5 } \\
\text { mRNA* }\end{array}$ & Eosinophil* & EG2* & CD25* \\
\hline Symptomatic & 1 & 14 & 23 & 12 & 2 \\
Symptomatic & 2 & 10 & 13 & 4 & 4 \\
Symptomatic & 3 & 7 & 13 & 5 & 3 \\
Symptomatic & 4 & 12 & 5 & 10 & 7 \\
Symptomatic & 5 & 6 & 5 & 5 & 1 \\
Symptomatic & 6 & 20 & 4 & 6 & 24 \\
Symptomatic & 7 & 0 & 1 & 3 & 0 \\
Asymptomatic & 8 & 0 & 3 & 3 & 1 \\
Asymptomatic & 9 & 0 & 1 & 1 & 0 \\
Asymptomatic & 10 & 0 & 0 & 2 & 0 \\
Normal & 11 & 0 & 0 & 0 & 0 \\
Normal & 12 & 0 & 1 & 1 & 0 \\
Normal & 13 & 0 & 0 & 0 & 0 \\
Normal & 14 & 0 & 0 & 1 & 0 \\
Normal & 15 & 0 & 1 & 1 & 0 \\
Normal & 16 & 0 & 0 & 1 & 0 \\
Normal & 17 & 0 & 0 & 0 & 0 \\
Normal & 18 & 0 & 1 & 1 & 0 \\
Normal & 19 & 0 & 0 & 0 & 0 \\
& & & & &
\end{tabular}

* Number of $+v e$ cells per millimeter length of basement membrane.

other four subjects does not necessarily indicate the absence of IL-5 production. It is possible that IL-5 mRNA may be generated in these subjects but below amounts detectable by in situ hybridization.

However, there was a trend for the asthmatics who exhibited a positive signal for the IL-5 mRNA to have more severe

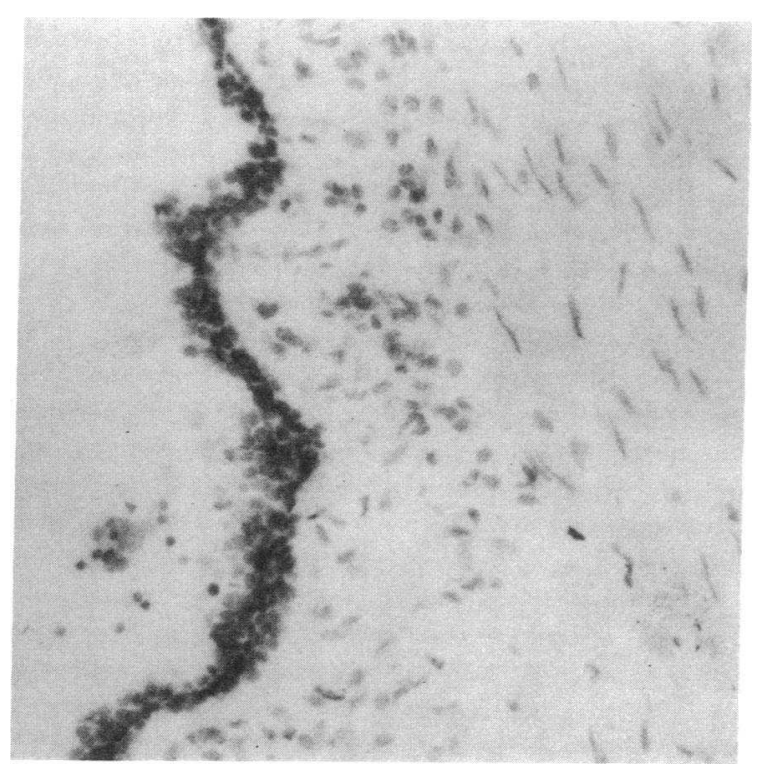

Figure 6. Autoradiograph of bronchial mucosa from normal subject. The section was hybridized with IL-5 cRNA probe. No hybridization signal was detected (magnification, 300).
Table III. Comparison of Chromotrope $2 R+, E G 2+$, and CD25+ Cells between the IL-5 MRNA+ and IL-5 mRNA-Biopsies

\begin{tabular}{lccc}
\hline $\begin{array}{c}\text { Total cell } \\
\text { counts* }\end{array}$ & $\begin{array}{c}\text { IL-5 } \text { mRNA }^{+} \\
\text {biopsies }\end{array}$ & $\begin{array}{c}\text { IL-5 mRNA } \\
\text { biopsies }\end{array}$ & $P$ values $^{*}$ \\
\hline Chromotrope 2R & $10.5(4-23)$ & $1.3(0-3)$ & 0.01 \\
EG2 positive & $7.0(4-12)$ & $2.3(1-3)$ & 0.01 \\
CD25 positive & $6.8(1-24)$ & $0.3(0-1)$ & $0.01-0.05$
\end{tabular}

* Per millimeter length of basement membrane expressed as mean and range. ${ }^{\ddagger}$ Comparison of cell counts in $\mathrm{IL}-5^{+}$vs. IL- $5^{-}$biopsies.

disease, as reflected by more frequent symptoms and increased bronchodilator usage. These patients also tended to have greater airflow obstruction and increased airway responsiveness, compared to the IL-5 mRNA-negative group, although the differences were not statistically significant, possibly due to the small number of subjects. Furthermore, the six IL-5 mRNA+ asthmatics showed significant increases in the numbers of activated $T$ cells and activated eosinophils when compared with the IL-5 mRNA ${ }^{-}$asthmatics. Within the asthmatic group, there were significant correlation between IL-5 mRNA+ cells and the number of activated T cells and eosinophils. This suggests that a positive signal for IL-5 generation correlates well with the extent of the inflammatory process in the airway mucosa. This further supports the hypothesis that IL-5 released by $T$ lymphocytes is involved in eosinophil recruitment and activation in asthma.

\section{Acknowledgments}

This work was supported by a Medical Research Council (UK) Programme grant awarded to A. B. Kay and a National Asthma Campaign (UK) grant to P. K. Jeffery and A. B. Kay.

\section{References}

1. Wardlaw, A. J., S. Dunnette, G. J. Gleich, J. V. Collins, and A. B. Kay 1988. Eosinophils and mast cells in bronchoalveolar lavage in mild asthma. Relationship to bronchial hyperreactivity. Am. Rev. Respir. Dis. 137:62-69.

2. De Monchy, J. G., H. F. Kauffman, P. Venge, G. H. Koeter, H. M. Jansen, H. J. Sluiter, and K. De Vries. 1985. Bronchoalveolar eosinophils during allergeninduced late asthmatic reactions. Am. Rev. Respir. Dis. 131:373-376.

3. Durham, S. R., and A. B. Kay. 1985. Eosinophils, bronchial hyperreactivity and late-phase asthmatic reactions. Clin. Allergy. 15:411-418.

4. Wegner, C. D., R. H. Gundel, P. Reilly, N. Haynes, G. L. Letts, and R. Rothlein. 1990. Intercellular adhesion molecule-1 (ICAM-1) in the pathogenesis of asthma. Science (Wash. DC). 247:456-459.

5. Gleich, G. J., E. Frigas, D. A. Loegering, D. L. Wassom, and D. Steinmuller. 1979. Cytotoxic properties of the eosinophil major basic protein. J. Im munol. 123:2925-2927.

6. Holgate, S. T., W. M. Abraham, P. J. Barnes, and T. H. Lee. 1899. Pharmacology and treatment. In The Role of Inflammatory Processes in Airway Hyperresponsiveness. S. T. Holgate, J. B. L. Howell, P. G. J. Burney, J. M. Drazen, F. E. Hargreave, A. B. Kay, K. F. Kerrebijn, and L. M. Reid, editors. Blackwell Scientific Publications, Oxford. 179-221.

7. Frew, A. J., and A. B. Kay. 1988. The relationship between infiltrating $\mathrm{CD}^{+}$lymphocytes, activated eosinophils and the magnitude of the allergen-induced late phase cutaneous reaction in man. J. Immunol. 141:4158-4164.

8. Metzger, W. J., D. Zavala, H. B. Richerson, P. Moseley, P. Iwamota, M. Monick, K. Sjoerdsma, and G. W. Hunninghake. 1987. Local allergen challenge and bronchoalveolar lavage of allergic asthmatic lungs. Description of the model and local airway inflammation. Am. Rev. Respir. Dis. 135:433-440.

9. Corrigan, C. J., A. Hartnell, and A. B. Kay. 1988. T-lymphocyte activation in acute severe asthma. Lancet. $i: 1129-1132$.

10. Azzawi, M., B. Bradley, P. K. Jeffery, A. J. Frew, A. J. Wardlaw, B. Assouf, J. V. Collins, S. R. Durham, G. K. Knowles, and A. B. Kay. 1990. 
Identification of activated $T$ lymphocytes and eosinophils in bronchial biopsies in stable atopic asthma. Am. Rev. Respir. Dis. 142:1407-1413.

11. Tai, P.-C., C. J. F. Spry, C. Peterson, P. Venge, and I. Olsson. 1984 Monoclonal antibodies distinguish between storage and secreted forms of eosinophil cationic peptide. Nature (Lond.). 309:182-184.

12. Clutterbuck, E. J., E. M. A. Hirst, and C. J. Sanderson. 1988. Human interleukin-5 (IL-5) regulates the production of eosinophils in human bone marrow cultures: comparison and interaction with IL-1, IL-3, IL-6 and GM-CSF. Blood. 73:1504-1513.

13. Lopez, A. F., C. J. Sanderson, J. R. Gamble, H. R. Campbell, I. G. Young, and M. A. Vadas. 1988. Recombinant human interleukin-5 is a selective activator of human eosinophil function. J. Exp. Med. 167:219-224.

14. Yamaguchi, Y., Y. Hayashi, Y. Sugama, Y. Miura, T. Kasahara, S. Kitamura, M. Torisu, S. Mita, A. Tominaga, K. Takatsu, and T. Suda. 1988. Highly purified murine interleukin-5 (IL-5) stimulates eosinophil function and prolong in vitro survival. J. Exp. Med. 167:1737-1742.

15. Coffman, L. R., W. B. Seymour, S. Hudak, J. Jackson, and D. Rennick 1989. Antibody to interleukin 5 inhibits helminth-induced eosinophilia in mice. Science (Wash. DC). 245:308-310.

16. Owen, W. F., M. E. Rothenberg, J. Petersen, P. F. Weller, D. Silberstein, A. L. Sheffer, R. L. Stevens, R. J. Soberman, and K. F. Austen. 1989. Interleukin5 and phenotypically altered eosinophils in the blood of patients with the idiopathic hypereosinophilic syndrome. J. Exp. Med. 170:343-348.

17. Walsh, G. M., A. Hartnell, A. J. Wardlaw, K. Kurihara, C. J. Sanderson, and A. B. Kay. 1990. IL-5 enhances the in vitro adhesion of human eosinophils but not neutrophils, in a leucocyte integrin (CD11/18)-dependent manner. Immunology. 71:258-265.

18. Campbell, H. D., W. Q. J. Tucker, Y. Hort, M. E. Martinson, E. J. Clutterbuck, C. J. Sanderson, and I. G. Young. 1987. Molecular cloning and expression of the gene encoding human eosinophil differentiation factor (interleukin-5). Proc. Natl. Acad. Sci. USA. 84:6629-6633.

19. Tavernier, J., R. Devos, J. Heypen, G. Hauquier, R. Bauden, I. Fache, E. Kawashima, J. Vendekerckhove, R. Contreras, and W. Fiers. 1989. Expression of human and murine interleukin-5 in eukaryocytic systems. DNA (NY). 8:491501.

20. Hamid, Q., J. Wharton, G. Terenghi, C. Hassall, J. Aimi, K. Taylor, H. Nakazato, J. Dixon, G. Burnstock, and J. M. Polak. 1987. Localisation of atria natiuretic peptide mRNA and immunoreactivity in rat heart and human atrial appendage. Proc. Natl. Acad. Sci. USA. 84:6760-6764.

21. Hamid, Q., A. Bishop, D. R. Springall, C. Adam, A. Giaid, P. Denny, M. A. Ghatei, S. Legon, F. Cuttitta, J. Rode, E. Spindle, S. R. Bloom, and J. M. Polak. 1989. Detection of human probombesin mRNA in small cell carcinoma of the lung. Cancer (Phila.). 63:266-271.

22. Quint, D. J., E. J. Bolton, L. A. McNamee, R. Solari, P. H. Hissey, B. R. Champion, A. R. MacKenzie, and E. D. Zanders. 1989. Functional and phenotypic analysis of human $T$ cell clones which stimulate IgE production in vitro. Immunology. 67:68-74.

23. Hoefler, H., H. Childers, M. R. Montiminy, R. M. Lechan, R. H. Goodmans, and H. J. Wolfe. 1986. In situ hybridisation of methods for the detection of somatostatin mRNA in tissue sections using antisense RNA probes. Histochem. J. 18:597-604.

24. Brady, M. A., and F. Finlan. 1990. Radioactive labels: autoradiography and choice of emulsion for in situ hybridization. In In Situ Hybridization: Principles and Practice. J. M. Polak, and J. McGee, editors. Oxford University Press, Oxford. 31-57.

25. Plaut, M., J. H. Pierce, C. J. Watson, J. Hanley-Hyde, R. P. Nordan, and W. E. Paul. 1989. Mast cell lines produce lymphokines in response to cross-linkage of Fc-epsilon RI or to calcium ionophores. Nature (Lond.). 339:64-67. 